\title{
VOORWOORD
}

\section{RADICALISERING VAN POL DE MONT TOT DE BELGISCHE WERKLIEDENPARTIJ}

Vorig jaar verscheen een vuistdikke biografie over Pol De Mont (1857-1931) van de literatuurhistoricus Ludo Stynen. ${ }^{1}$ Het boek krijgt een recensie in een van de volgende nummers van WT. In dit nummer bezorgt de auteur een artikel over een episode uit het leven van De Mont die in de biografie - meer dan 500 pagina's - niet kon worden uitgediept, mede door de overvloed aan primair bronnenmateriaal dat over de studentenleider, dichter, criticus, redenaar, volkskundige, leraar, kunsthistoricus en conservator van het Antwerpse Museum voor Schone Kunsten beschikbaar is. Het handelt over De Mont als hoofdredacteur van de krant De Schelde (1919-1923) en de honderden stukken die hij schreef in deze in Antwerpen gedrukte spreekbuis van de Frontpartij. In het bijzonder wordt De Monts ideologische positionering behandeld. De veertig jaar voordien had hij al heel wat levensbeschouwelijke waters doorzwommen. In Leuven was hij actief in het katholieke studentenleven aan de zijde van Rodenbach, maar al gauw viel hij van zijn geloof, bekeerde zich tot een persoonlijk theosofisch deïsme en trad later toe tot de loge. Als leraar aan het Atheneum van Antwerpen werd hij liberaal en fel antiklerikaal, maar tevens voorstander van samenwerking over de geloofsgrenzen heen rond een flamingantisch programma. Hij was uiterst actief in de strijd voor vernederlandsing van de Gentse universiteit en andere Vlaamsgezinde strijdpunten. Als sympathisant van het pangermaans Alldeutscher Verband zag hij de Vlaamse beweging als een 'voorpostengevecht tussen het Duitse of Germaanse ras en het Latijnse', maar in België zelf faciliteerde het samenleven van die twee culturen de uitwisseling van cultuur. De Mont verklaarde zich een Belgisch patriot en verbrandde zich tijdens de Eerste Wereldoorlog niet aan het activisme maar hij kwam er dicht genoeg bij waardoor zijn politieke tegenstanders voldoende munitie hadden om hem aan te vallen wegens onvaderlands gedrag. Hij hield er een zenuwinzinking aan over en zag zich gedwongen vervroegd met pensioen te gaan als conservator. Na de oorlog zocht en vond De Mont een nieuwe baan als hoofdredacteur van De Schelde en kon zo 'thuiskomen in het Vlaams-nationalisme'. Hij ijverde voortaan voor Vlaams zelfbestuur, moest niets meer weten van 'kastraten' als Frans Van Cauwelaert en andere minimalisten en rekende op mannen met 'teelballen' zoals Staf De Clercq. 
Ook Harry Van Velthoven beschrijft een proces van radicalisering in het tweede deel van zijn belangwekkend artikel over de geschiedenis van de communautaire spanningen in de BWP. ${ }^{2}$ Het Compromis des socialistes belges van november 1929 dat de facto het Minimumprogramma als uitgangspunt had, deed de communautaire spanningen in de partij slechts tijdelijk afnemen. Een nieuwe generatie zelfbewuste Vlaamse socialisten accepteerden de paternalistische taaldiscriminatie in de socialistische partijstructuren niet langer. Ze vroegen taalgebonden secties op de partijcongressen. Het leidde tot de invoering van simultaanvertaling, maar die maatregel kon niet voorkomen dat Vlaams en Waalse socialisten ook aparte congressen hielden vanaf 1937. De BWP groeide communautair uiteen ook op andere dan taalkwesties. "Notre parti est malade", concludeerde de Luikse socialist Joseph Merlot in mei 1939 nadat hij zijn ministerportefeuille verloor door de val van de regering-Spaak. Aanleiding was de affaire Martens waarbij de Vlaamse en Waalse socialisten in blok verdeeld hadden gestemd in het parlement. De malaise was zo groot dat de unitaire werking van de BWP in het gedrang kwam. Einde 1938, kort voor zijn dood, had Emile Vandervelde, de 'patron' die de partij decennia had geleid, al gewarschuwd dat de BWP evolueerde naar het katholieke model, refererend aan het uiteenvallen van de Katholieke Partij langs de taalbreuklijn in 1936.

Het is te verleidelijk om niet te speculeren hoe België politiek en staatkundig zou zijn geëvolueerd zonder een tweede Duitse bezetting. Zou het regionaliseringsproces vroeger zijn opgestart en zou de dynamiek en (voorlopige) uitkomst anders zijn geweest?

Bruno De Wever, hoofdredacteur

2 Het eerste deel over de periode 1919-1935 verscheen in WT, jg. 77, 2018, nr. 1, pp. $27-72$. 